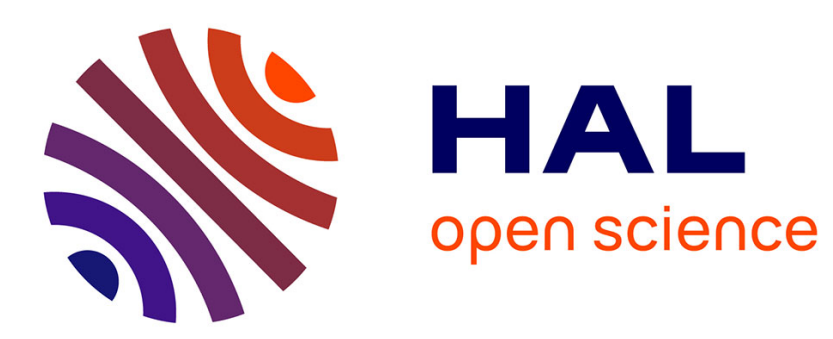

\title{
Engineering cytochrome P450 monooxygenase CYP 116B3 for high dealkylation activity
}

\author{
Luo Liu, Rolf D. Schmid, Vlada B. Urlacher
}

\section{To cite this version:}

Luo Liu, Rolf D. Schmid, Vlada B. Urlacher. Engineering cytochrome P450 monooxygenase CYP 116B3 for high dealkylation activity. Biotechnology Letters, 2010, 32 (6), pp.841-845. 10.1007/s10529010-0233-9 . hal-00574012

\section{HAL Id: hal-00574012 \\ https://hal.science/hal-00574012}

Submitted on 7 Mar 2011

HAL is a multi-disciplinary open access archive for the deposit and dissemination of scientific research documents, whether they are published or not. The documents may come from teaching and research institutions in France or abroad, or from public or private research centers.
L'archive ouverte pluridisciplinaire HAL, est destinée au dépôt et à la diffusion de documents scientifiques de niveau recherche, publiés ou non, émanant des établissements d'enseignement et de recherche français ou étrangers, des laboratoires publics ou privés. 


\title{
Engineering cytochrome P450 monooxygenase CYP $116 B 3$ for high dealkylation activity
}

\author{
Luo Liu • Rolf D. Schmid • Vlada B. Urlacher
}

Received: 17 December 2009/Revised: 3 February 2010/Accepted: 8 February 2010/Published online: 7 March 2010

(C) Springer Science+Business Media B.V. 2010

\begin{abstract}
Cytochrome P450 monooxygenase CYP116B3 from Rhodococcus ruber catalyzes the dealkylation of 7-ethoxycoumarin and the hydroxylation of substituted and unsubstituted aromatics. However, since activities were quite low, a combination of site-specific mutagenesis and directed evolution was applied to produce 7800 variants of CYP116B3, which were screened via a newly developed highthroughput screening system based on the dealkylation of 7-ethoxycoumarin catalyzed by recombinant E. coli. The best mutant was found after four rounds of directed evolution and had a 240 -fold increased deethylation activity toward 7-ethoxycoumarin (223 nmol product/nmol P450.min) and a 10-fold increased demethylation activity toward 7-methoxycoumarin ( $9 \mathrm{nmol}$ product/nmol P450.min).
\end{abstract}

Keywords Cytochrome P450 - Dealkylation · Directed evolution · High-throughput screening

\section{Introduction}

The cytochrome P450 enzymes (P450s or CYPs) constitute a large super-family of heme-thiolate proteins currently comprising well over 11500 distinct

L. Liu · R. D. Schmid · V. B. Urlacher $(\square)$ Institute of Technical Biochemistry, University of Stuttgart, Allmandring 31, 70569 Stuttgart, Germany e-mail: Vlada.Urlacher@itb.uni-stuttgart.de sequences from all phyla including animals, plants, fungi, and bacteria (http://drnelson.utmem.edu/cyto chromeP450.html) (Nelson 2009). Cytochrome P450s catalyze monooxygenase reactions that introduces $\mathrm{O}_{2}$ into generally non-polar, aromatic or aliphatic molecules, thereby leading to hydroxylation, dealkylation, aromatization, epoxidation or cleavage of carboncarbon bonds (Mansuy 1994; Sono et al. 1996; Cryle et al. 2003). Because of their unique and versatile catalytic properties, $\mathrm{P} 450$ s are of interest as potential biocatalysts for industrial applications. However, most $\mathrm{P} 450$ s display rather low activity and stability and therefore need to be optimized to fulfil the technical requirements (Urlacher and Eiben 2006).

Site-specific mutagenesis or directed evolutionas well as a combination of both-can be applied to improve or change enzyme features. A great advantage of directed evolution techniques is that they can be applied without structural knowledge of a protein (Arnold and Georgiou 2003). Methods of directed evolution alone or in combination with site-specific mutagenesis have successfully been used to engineer bacterial P450s. For example, the self-sufficient fatty acid hydroxylase P450 BM-3 from Bacillus megaterium (Munro et al. 2002) was engineered for oxidation of $n$-alkanes (Farinas et al. 2001), terpenoids (Urlacher et al. 2006) and human metabolites (Otey et al. 2006). Furthermore, using error-prone PCR the stability of this enzyme in the presence of organic solvents was improved significantly (Wong et al. 2004). 
The results of those studies demonstrate that the success of directed evolution experiments is often depended on the efficiency of the screening methods applied, since a large number of variants is usually generated and must be tested (Olsen et al. 2000).

Previously, we isolated and characterized CYP116B3 from Rhodococcus ruber DSM 44319 (Liu et al. 2006). The enzyme is a self-sufficient fusion protein consisting of a heme-containing $\mathrm{P} 450$ domain, a FMN-containing reductase and a $2 \mathrm{Fe}-2 \mathrm{~S}$-ferredoxin. CYP116B3. It catalyzes the dealkylation of 7-ethoxycoumarin and the hydroxylation of several substituted and unsubstituted aromatic hydrocarbons in the presence of NADPH. However, the activity was low in all cases. A turnover rate of $0.9 \mathrm{nmol} / \mathrm{nmol} \mathrm{P} 450$.min was determined for the dealkylation of 7-ethoxycoumarin by wild-type CYP116B3, which is one order of magnitude lower compared to the activity of $\mathrm{P} 450$ BM-3 toward its physiological substrates fatty acids (Munro et al. 2002).

To improve the activity of CYP116B3, we first applied site-specific mutagenesis followed by four rounds of directed evolution. The best enzyme found was a quintuple mutant, which demonstrated a 240fold increased deethylation activity toward 7-ethoxycoumarin and a 10-fold increased demethylation activity toward 7-methoxycoumarin.

\section{Materials and methods}

Materials and stains

7-Ethoxycoumarin, 7-methoxycoumarin, and 7-hydroxycoumarin were purchased from Sigma-Aldrich (Germany). All other chemicals were purchased from Fluka (Switzerland).

Site-specific mutagenesis

The structure of the heme domain of CYP116B3 was modeled using the program Modeller 8v2 (http:// salilab.org/index.html). The replacement of alanine at position 109 by phenylalanine was performed using the Quick-Change Kit (Stratagene) as recommended by the manufacturer. The plasmid pET28a $(+)_{-}$ CYP116B3 constructed previously (Liu et al. 2006) was used as template. The primers for PCR were designed as follows: 5'-CGACTACGCCATGTTCC GGACCCTCGTGAACG- $3^{\prime}$ and 5'-CGTTCACGA GGGTCCGGAACATGGCGTAGTCG- ${ }^{\prime}$. The mutation sites are underlined. All mutants were expressed in E. coli BL21(DE3) (Novagen, UK) and characterized as previously described (Liu et al. 2006).

\section{Error-prone PCR}

The E. coli NovaBlue(DE3) strain (Novagen, UK) was used as an expression host. Random libraries were generated by error-prone PCR using the plasmid pET28a(+) harboring the CYP116B3_A109F gene as template. Mutagenesis was performed only on the heme domain. The following primers were used: 5'-TAATACGACTCACTATAGGG- ${ }^{\prime}$ and 5'-TGT TCGTGGACGTAGCGCGA-3' . Taq-polymerase was chosen because of its high natural error rate. The error-prone PCR reaction mixtures contained $1.5 \mathrm{mM}$ $\mathrm{MgCl}_{2}$ for stabilization of non-complementary pairs. Unequal dNTPs concentrations, $0.05 \mathrm{mM} \mathrm{MnCl}_{2}$ and $0.05 \mathrm{mM}$ dITP were applied to increase the error rate during PCR.

Primary screening for enzyme activity on a multiwell plate scale

Expression of the CYP116B3 wild-type enzyme and mutants in $E$. coli NovaBlue(DE3) was performed in deep-well plates (Greiner Bio-One GmbH, Germany). Each well, containing $600 \mu \mathrm{l}$ LB-medium supplemented with $50 \mathrm{mg}$ kanamycin/l and $5 \mathrm{mg}$ thiamine/l was inoculated with a single colony. Cells were grown at $37^{\circ} \mathrm{C}, 200 \mathrm{rpm}$ for about $4.5 \mathrm{~h}$ to an $\mathrm{OD}_{590}$ of $\sim 0.35$. P450 expression was induced by addition of $0.4 \mathrm{mM}$ IPTG. The cells were cultivated further for $24 \mathrm{~h}$ at $30^{\circ} \mathrm{C}, 180 \mathrm{rpm}$. The plates were centrifuged at $4,000 \times \mathrm{g} / \mathrm{w}, 4^{\circ} \mathrm{C}$ for $30 \mathrm{~min}$. The supernatants were discarded and cell pellets resuspended in $190 \mu \mathrm{l}$ $50 \mathrm{mM}$ potassium phosphate buffer $(\mathrm{pH} 7.5)$ and transferred into black 96-well plates FluoroNunc (Sigma-Aldrich). Each well was supplemented with $10 \mu \mathrm{l} 25 \mathrm{mM}$ 7-ethoxycoumarin (dissolved in DMSO). The 96-well plates were immediately put into a multiwell plate reader (FLUOstar, BMG) and the fluorescence intensity of the product, 7-hydroxycoumarin (excitation at $405 \mathrm{~nm}$, emission at $460 \mathrm{~nm}$ ), was measured. The measurements were carried out for nine cycles with $90 \mathrm{~s}$ intervals. 
Secondary screening

To sort out false positive clones, the best candidate mutants were expressed in shaking flasks containing $100 \mathrm{ml} \mathrm{LB}$ medium supplemented with $50 \mathrm{mg}$ kanamycin/l. Expression and enzyme activity measurements were performed as previously described (Liu et al. 2006). Concentrations of CYP116B3 variants were calculated from CO-difference spectra as described elsewhere (Omura and Sato 1964). Finally the best variants were validated by automated DNA sequencing (GATC Biotech, Konstanz, Germany). All experiments were performed at least three times in duplicate.

\section{Results and discussion}

Since the crystal structure of CYP116B3 has not yet been solved, a homology model of the heme domain was created based on sequence alignments and crystal structures of P450 terp (CYP108A1) (PDB ID, 1CPT), $\mathrm{P}^{4} 0_{\text {epoK }}$ (CYP167A1) (PDB ID, 1PKF), and P450 eryF (CYP107A1) (PDB ID1Z8O). Examining the homology model revealed a small region at the ceiling of the substrate binding pocket which might control enzyme activity. Since the alanine at position 109 within this region is located directly above the heme group, we expected that introduction of the bulky amino acid phenylalanine at this position would facilitate better stabilization of smaller molecules and thus result in enhanced activity and/or regioselectivity. Indeed, the single mutant CYP116B3 A109F demonstrated nearly 3-times higher activity toward 7-ethoxycoumarin and PAHs (naphthalene, indene, acenaphthene, toluene, fluorene, $m$-xylene and ethyl benzene) compared to the wild-type enzyme. However, the substrate specificity and regioselectivity of this mutant remained unchanged.

As directed evolution does not require any structural information for construction of a random mutant library, we decided to apply this approach for further improvement of CYP116B3. A random mutant library was generated by error-prone PCR. The most critical step during directed evolution is the development of a simple, reproducible and fast high-throughput screening (HTS) for the direct measurement of enzyme activity. Since P450s depend on the delivery of electrons, which are in most cases ultimately delivered from $\mathrm{NAD}(\mathrm{P}) \mathrm{H}$, it is possible to follow $\mathrm{NAD}(\mathrm{P}) \mathrm{H}$ oxidation at $340 \mathrm{~nm}$. However, the enzyme/substrate match is often sub-optimal and results in reducing equivalents from $\mathrm{NAD}(\mathrm{P}) \mathrm{H}$ being channeled away from product formation to give instead hydrogen peroxide and water (so called "uncoupling"). NAD(P)H consumption and product formation are therefore not always correlated. More accurate and precise methods are based on direct measurements of substrate consumption or product formation. Fortunately 7-hydroxycoumarin is fluorescent and its formation can be monitored directly. Therefore this method was used for activity screenings within this study.

To avoid the tedious cell lysis and high costs for the co-factor NADPH, the activity screening was carried out with resting E. coli cells in 96-well plates. Expression of CYP116B3 in LB-medium showed better results compared to those achieved with TBmedium. Interestingly, the addition of a heme precursor, 5-aminolevulinic did not affect the expression level of CYP116B3.

The first set of experiments was performed with $1.2 \mathrm{mg}$ resting cells (cell wet wt) expressing wildtype CYP116B3 to investigate if the dealkylation activity of the enzyme could be measured with recombinant $E$. coli. Effect of the cell permeabilizer polymyxin B was also investigated. E. coli containing the plasmid pET28a(+) (as purchased from the manufacturer) was used as a negative control. A positive control was performed with cell lysates containing CYP116B3 isolated from an equivalent amount of recombinant $E$. coli. Utilizing this set-up, dealkylation activity of CYP166B3 could be measured with whole E. coli cells and addition of the permeabilizer, polymyxin $\mathrm{B}$, did not affect the screening results (Table 1).

The single mutant A109F was used as template for the first round of error-prone PCR. Statistical analysis of the results gained in the primary screening revealed that $35 \%$ of the generated clones were inactivated through mutagenesis. Since enzyme activity in the whole-cell assay could not be normalized to the enzyme concentration, it was not possible to distinguish between false positive clones (originating from high amounts of cells and/or higher expression of CYP116B3) from clones with enhanced specific activity. Consequently, the most active clones yielding double at least the fluorescence response of A109F were applied to a secondary screening. 
Table 1 Activity of recombinant E. coli cells toward 7-ethoxycoumarin in the presence and absence of polymyxin B in a total reaction volume of $200 \mu \mathrm{l}$

\begin{tabular}{lcl}
\hline Biocatalyst & Polymyxin B $(\mu \mathrm{M})$ & Activity $(\mu \mathrm{M} / \mathrm{min})$ \\
\hline $1.2 \mathrm{mg} \mathrm{CWW}$ & - & 0.19 \\
$1.2 \mathrm{mg} \mathrm{CWW}$ & 60 & 0.18 \\
Cell lysate $^{\mathrm{a}}$ & - & 0.17
\end{tabular}

If polymyxin treatment was applied, $20 \mu \mathrm{l} 0.6 \mathrm{mM}$ polymyxin $\mathrm{B}$ (dissolved in $50 \mathrm{mM}$ potassium buffer, $\mathrm{pH} 7.5$ ) was added to $160 \mu \mathrm{l}$ cell suspension. The positive control was represented by cell lysate derived from $1.2 \mathrm{mg} E$. coli cells. No activity was detected in the negative control with $E$. coli cell harboring pET28a(+)

$C W W$ cell wet weight

a $10 \mu \mathrm{l}$ of cell lysate derived from $1.2 \mathrm{mg} \mathrm{CWW}$, contain $0.18 \mu \mathrm{M}$ CYP116B3

The secondary screening was performed in shaking flasks as described in the "Materials and methods" section. Concentrations of CYP116B3 variants in the soluble protein fractions after cell lysis were calculated and the specific activities toward 7-ethoxycoumarin were determined (Table 2). Only three out of 12 variants exhibited increased specific activity, whereas other "positive" variants were assigned as false positives. The variant 4E01 had the highest specific activity but was poorly stable under the expression conditions applied. We decided to exclude this variant and continue our experiments with variant 7F08 that demonstrated high activity and stability upon expression. DNA-sequencing of variant 7F08 revealed that isoleucine at position 267 was replaced by leucine. This double CYP116B3 mutant A109F/I267L was used as template for the second round of error-prone PCR.

Three additional rounds of directed evolution were carried out according to the procedure described above, and 7800 variants were screened in total. After the fourth round of error-prone PCR, the activity toward 7-ethoxycoumarin could be increased from $2.6 \mathrm{nmol} / \mathrm{nmol} \mathrm{P} 450 . \mathrm{min}$ (measured with the single mutant A109F) to $141 \mathrm{nmol} / \mathrm{nmol} \mathrm{P} 450 . \mathrm{min}$ (variant 74H10, T91S/A109L/I179F/I267L) and to $223 \mathrm{nmol} /$ nmol P450.min (variant 70A08, A86T/T91S/A109F/ I179F/I267L) (Table 3). Interestingly, phenylalanine at position 109 was substituted by leucine in variant $74 \mathrm{H} 10$, which is the position that was originally chosen for site-specific mutagenesis.
Table 2 Dealkylation activity of 12 variants chosen from the primary screening

\begin{tabular}{ll}
\hline Variants & $\begin{array}{l}\text { Product formation rate } \\
\text { (nmol/nmol P450.min) }\end{array}$ \\
\hline 2A09 & 5.41 \\
4A08 & 1.27 \\
4A09 & 1.26 \\
4A10 & 1.37 \\
4E01 & 7.22 \\
4G10 & 1.48 \\
5F11 & 1.13 \\
7A10 & 1.61 \\
7E09 & 1.62 \\
7F08 & 6.67 \\
8A05 & 1.6 \\
8A10 & 1.7
\end{tabular}

Activity was measured with cell lysates as described in the "Materials and methods" section

We also determined the activity of the two best mutants, $74 \mathrm{H} 10$ and 70A08, toward coumarin and its derivative 7-methoxycoumarin. Both mutants accepted 7-methoxycoumarin as substrate and demonstrated increased specific activity up to $9 \mathrm{nmol} /$ nmol P450.min. However, no hydroxylation activity toward coumarin was observed. Furthermore, other substrates of wild-type CYP116B3 including naphthalene, indene, acenaphthene, toluene, fluorene, $m$-xylene, and ethyl benzene were tested. However, neither the variant 70A08, nor 74H10 displayed enhanced activity toward any of those substrates.

\section{Conclusions}

Using site-specific mutagenesis at position 109 the dealkylation activity of CYP116B3 was increased 3 -fold compared to the wild-type enzyme. A CYP116B3 mutant library was generated by four rounds of error-prone PCR to further enhance the enzyme's activity. A newly developed high throughput screening utilizing resting recombinant $E$. coli cells was applied for library screening. Finally, two mutants, 70A08 (A86T/T91S/A109F/I179F/I267L) and 74H10 (T91S/A109L/I179F/I267L), were identified that exhibited 150 - or 240-fold increased dealkylation activity. Several "hotspot" positions have been identified in the substrate binding pocket and on the surface 
Table 3 Activity of wild-type CYP116B3 and the best mutants toward 7-ethoxycoumarin (7-EC) and 7-methoxycoumarin (7-MC)

\begin{tabular}{|c|c|c|c|c|}
\hline \multirow{2}{*}{$\begin{array}{l}\text { Round of error-prone } \\
\text { PCR/Enzyme }\end{array}$} & \multirow{2}{*}{$\begin{array}{l}\text { Nucleotide } \\
\text { substitution }^{\text {a }}\end{array}$} & \multirow{2}{*}{$\begin{array}{l}\text { Amino acid } \\
\text { substitution }^{\mathrm{a}}\end{array}$} & \multicolumn{2}{|c|}{ Product formation rate $(\mathrm{nmol} / \mathrm{nmol}$ P450.min) } \\
\hline & & & 7-EC & 7-MC \\
\hline Wild-type & & & 0.9 & 0.7 \\
\hline \multirow[t]{2}{*}{ A109F } & $325 \mathrm{G} \rightarrow \mathrm{T}$ & $\mathrm{A} 109 \mathrm{~F}$ & 3 & n.d. \\
\hline & $326 \mathrm{C} \rightarrow \mathrm{T}$ & & & \\
\hline 1st round/07F08 & $799 \mathrm{~A} \rightarrow \mathrm{C}$ & I267L & 7 & n.d. \\
\hline 2nd round/30A06 & $256 \mathrm{G} \rightarrow \mathrm{A}$ & A86T & 30 & n.d. \\
\hline 3 rd round/44G08 & $535 \mathrm{C} \rightarrow \mathrm{T}$ & L179F & 100 & n.d. \\
\hline 4 th round $/ 70 \mathrm{~A} 08$ & $271 \mathrm{~A} \rightarrow \mathrm{T}$ & T91S & 223 & 9.2 \\
\hline 4 th round $/ 74 \mathrm{H} 10$ & $325 \mathrm{~T} \rightarrow \mathrm{C}$ & A109L & 141 & 8.2 \\
\hline
\end{tabular}

n.d. not detectable

a The nucleotide substitution(s) and corresponding amino acid change(s) introduced in each round of mutagenesis are indicated

of CYP116B3, which can be applied to further sitespecific or saturation mutagenesis studies. Nevertheless, the correlation between the mutated positions and activity of the respective mutants will not be discussed herein, since a detailed protein structure is not available yet.

Acknowledgments We thank Marco Girhard and Clemens von Buhler for constructive discussions and critical review of the manuscript.

\section{References}

Arnold FH, Georgiou G (2003) Directed evolution library creation: methods and protocols. Humana Press Inc., Totowa, New Jersey

Cryle MJ, Stok JE, De Voss JL (2003) Reactions catalyzed by bacterial cytochromes P450. Aust J Chem 56:749-762

Farinas ET, Schwaneberg U, Glieder A, Arnold FH (2001) Directed evolution of a cytochrome P450 monooxygenase for alkane oxidation. Adv Synth Catal 343:601-606

Liu L, Schmid RD, Urlacher VB (2006) Cloning, expression, and characterization of a self-sufficient cytochrome $\mathrm{P} 450$ monooxygenase from Rhodococcus ruber DSM 44319. Appl Microbiol Biotechnol 72:876-882
Mansuy D (1994) Cytochromes P450 and model systemsgreat diversity of catalyzed reactions. Pure Appl Chem 66:737-744

Munro AW, Leys DG, McLean KJ, Marshall KR, Ost TWB, Daff S, Miles CS, Chapman SK, Lysek DA, Moser CC, Page CC, Dutton PL (2002) P450BM3: the very model of a modern flavocytochrome. Trends Biochem Sci 27:250-257

Nelson DR (2009) The cytochrome P450 homepage. Hum Genomics 4:59-65

Olsen M, Iverson B, Georgiou G (2000) High-throughput screening of enzyme libraries. Curr Opin Biotechnol 11:331-337

Omura T, Sato RJ (1964) The carbon monoxide-binding pigment of liver microsomes. J Biol Chem 239:2370-2378

Otey CR, Bandara G, Lalonde J, Takahashi K, Arnold FH (2006) Preparation of human metabolites of propranolol using laboratory-evolved bacterial cytochromes P450. Biotechnol Bioeng 93:494-499

Sono M, Roach MP, Coulter ED, Dawson JH (1996) Hemecontaining oxygenases. Chem Rev 96:2841-2888

Urlacher VB, Eiben S (2006) Cytochrome P450 monooxygenases: perspectives for synthetic application. Trends Biotechnol 24:324-330

Urlacher VB, Makhsumkhanov A, Schmid RD (2006) Biotransformation of beta-ionone by engineered cytochrome P450 BM-3. Appl Microbiol Biotechnol 70:53-59

Wong TS, Arnold FH, Schwaneberg U (2004) Laboratory evolution of cytochrome P450BM-3 monooxygenase for organic cosolvents. Biotechnol Bioeng 85:351-358 